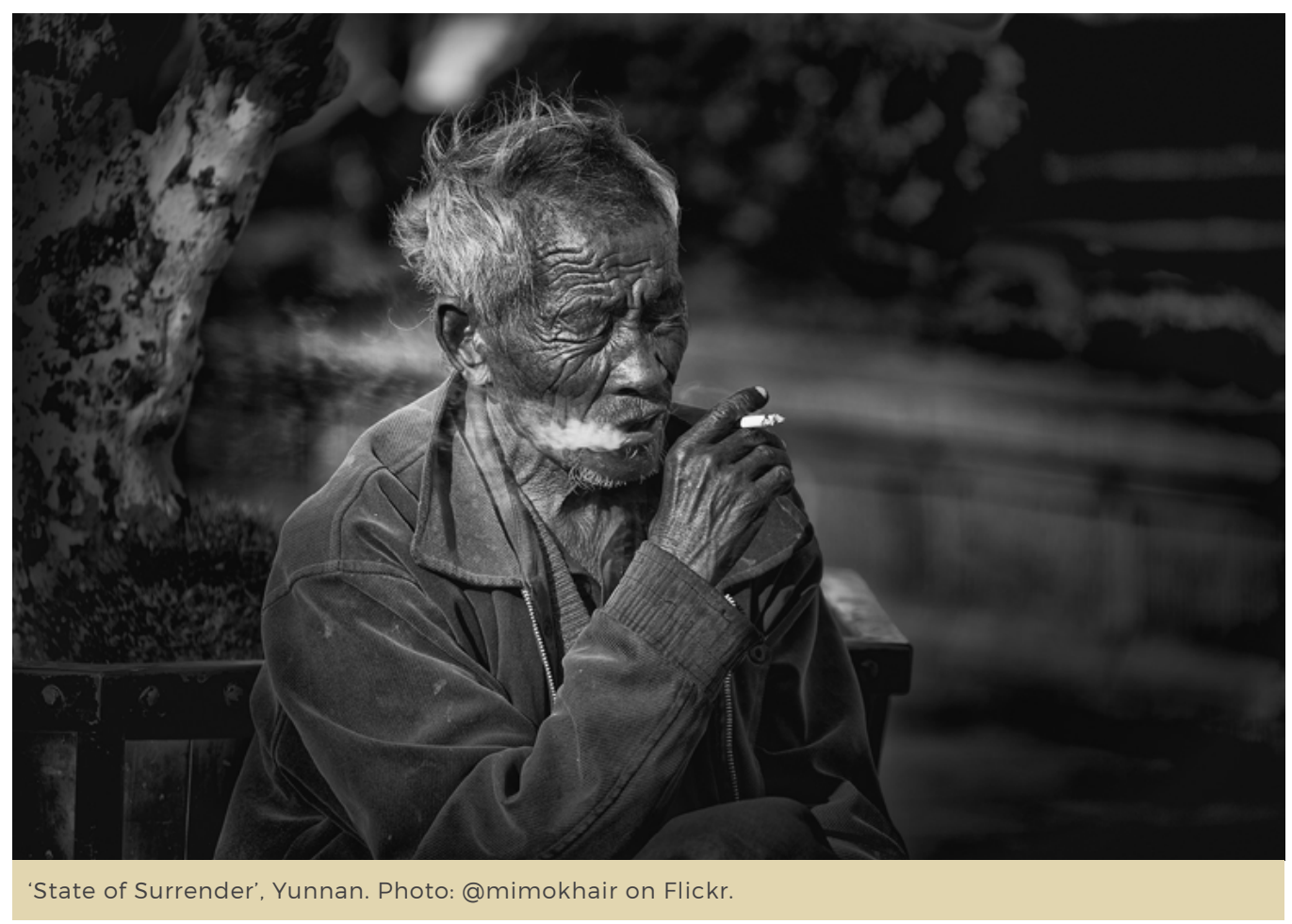

\section{The Precarity of Layoffs and State Compensation The Minimum Livelihood Guarantee}

\section{Dorothy J. Solinger}

When discussing the outcomes of China's economic development, the poverty that can still be found in Chinese cities is seldom mentioned. While the Party-state is indeed making a token effort to sustain the victims of this destitution, these people and their offspring will never be able to escape this manufactured poverty. This essay looks at the policy process that led to this outcome and at the prospects for poverty alleviation in Chinese urban areas.
When discussing the results of China's 'miracle' development over the past four decades, it is common enough to hear about the large numbers of rural Chinese citizensespecially those residing in designated poor counties-who have been 'lifted out of poverty' by the policies of the government, or about the surging numbers of the 'new middle class', or else, often enough, about the infamous urban-rural income dividewhich suggests that all those in urban areas are well off if they have the good fortune to hold an urban household registration. But, by contrast, we hear almost nothing about the poverty and attendant precarity found in the cities, which the state itself has engendered. The state makes a token effort to sustain the victims of this destitution, but it is clear they will never be able to escape this manufactured poverty, nor will their offspring. How many of them are there and how did this transpire? 


\section{Manufacturing Precarity in the State Sector}

It is easier to document the regime choices and the process that produced this outcome, and to describe the programme intended to maintain the status quo, than to estimate the number of people affected. But tens of millions would be a fair guess. The choices of the Chinese leadership had much to do with China's aim for a type of modernity characterised by participation in global competition, spurred on by the country's preparation to enter the World Trade Organisation (WTO) in the late 1990s. The lot of China's laid-off workers, therefore, rightly fits within the rubric of the types of precarity attending the life of labourers around the world. This shift towards integration into the global economy overlapped with an official diagnosis of the failure of the planned economy and of its unsuitability for participation in the modern world market, which was ultimately responsible for driving huge numbers of state-owned firms into the red by the mid1990s.

As a consequence of those glances both ahead and into the past, on the eve of China's accession to the WTO the decision makers at the helm of the state determined that firms losing money were not just a significant drain on the state budget, but also-and perhaps even more critically-incapable of competing in the world market, due to their unskilled workforces and obsolete technology. For this reason, they had to be shut down, with their workers dismissed from their jobs in droves. Figures vary, but in recent years most observers agree that the total of those let go may well have exceeded sixty million (Hussain 2003).

So a project termed 'enterprise restructuring' (qiye gaizhi) was set into motion from 1997 to 1999, following the principle of 'grasping the big and letting go the small' (zhuada fangxiao). This amounted to allowing the smaller firms, and those in non-strategic sectors, to fail; it also meant permitting the more successful enterprises to take over anything of value from the weaker ones-primarily by way of mergers or buyouts. Complex arrangements sometimes ensued, but the upshot for my argument here is to highlight the emergence of mass unemployment for many millions of olderthat is over the age of thirty-five!-state workers, whose education was deficient because of the closure of schools during the Cultural Revolution. Deemed worthless, these people were often forced to make do on their own. Certainly, a huge increase in urban poverty occurred at that time, affecting perhaps some 15 to 20 percent of the urban population if dependents of the laid-off workers are included, and nothing serious has been done to remove this blight.

A hastily assembled plan called the 'Reemployment Project' (zaijiuye gongcheng) was put into action in 1998. It was supposed to be underwritten by enterprises, localities, and 'society', with the aim of supplying training, finding jobs, and distributing 'basic livelihood allowances' (jiben shenghuofei) for the furloughed. But in fact, many workers received no funds, and even for those who did, the amount they were given was grossly inadequate. Moreover, indebted or bankrupt firms were not able to contribute to the collections, and the rate of re-employment even after a few years fell below 20 percent (Wu and Huang 2007).

\section{Minimum Livelihood Allowance as a Tranquiliser}

\footnotetext{
Workers responded by protesting vociferously in many cities, causing disruptions (Hurst 2009). Central leaders understandably became anxious, first about the instability itself, and then about what
} 
they deemed to be the likely impact on their visions of enterprise 'reform', and what such disorder might spell for discouraging foreign investment. The judgment of the political elites was that a 'tranquiliser', in the form of a 'minimum livelihood allowance' (zuidi shenghuo baozhang, or dibao), was to be provided to all urban citizens whose families' average household income fell below a locally set poverty line. Thus, the leadership expanded a scheme pioneered in Shanghai in 1993, decreeing that it was to be adopted in every city by the fall of 1999 . The sums dispensed were trivial, whether considered as a percentage of gross domestic product (GDP), or as compared with average levels of disposable income in the various localities.

The programme is means tested, meagre, and stigmatising. It entails cash transfers, requiring no contributions, but it also sets no conditions, such as demanding that mothers ensure that their children see doctors and go to school (as is the case for other social relief plans elsewhere in the world). Thus, it seems indifferent as to whether it lays out a path to eventual, inter-generational departure from penury.

As of the mid-2000s, soon after the birth of the programme, about 4 percent of the urban populace was being served, a percentage that remains pretty much the same today nationally. But at that time researchers figured that something like twice that percentage of the people had net incomes below the poverty line in their own cities (Lou and Wang 2008). More than that, yesterday as today, a frequently bemoaned 'preference for friends and relatives' has placed the allotments into hands that do not deserve it, overlooking often enough those who do need assistance.

In addition, as the years passed, by the end of the decade able-bodied unemployed people were advised to find work for themselves, even as the labour market was decidedly unfriendly to these 'aged', under- educated, and sometimes disabled or ill former workers. Many of them were unable to leave their homes, as they had no choice but to tend to their own sick, infirm, and young, since their scant incomes prohibited them from hiring any help.

\section{Perspectives from the Beneficiaries}

How do the recipients of this assistance experience their situation? The following excerpt reveals how they struggle to get along. When asked what they would like to see the government do for them, here is what a recipient said:

Recipient: First, supply some regular jobs; second, when you do a little business, shouldn't the government's policy tilt to you? If the government doesn't help, we certainly don't have the strength to assist ourselves.

Interviewer: To help the recipients of dibao throw off poverty, are jobs the root cure?

Recipient: Yes. Otherwise, just give more money, but it's not possible, giving us one third of the average wage is not possible. If the state's finance really has this ability, why can't it adjust employment policy? I feel that at the present stage the state should raise [our allowance] a little, price inflation now is so severe! The prices of so many things have risen, how can this be tolerated? The recipients of dibao are already very low on money, you could give them a little more. Public officials and government cadres don't care about inflation, if you give them two hundred yuan [at the time of the interview, that would have been about twenty-five USD], or five hundred yuan, it won't count for much. But for the recipients of dibao, if you give them ten yuan or twenty yuan it has a function. But the state can't simply give you more money, so I say it's employment. Really getting rid of the dibao would be good. Having some stable work instead, wouldn't that be even better? 
The programme often comes under suspicion because people assume that it enables laziness and a reluctance to work. And yet other interview subjects agreed with the sentiments of the interviewee quoted above. In 2010, a beneficiary of the programme in Guangzhou-a man who was half-paralysed and had both high blood pressure and diabetes-still wished to work. In his words: 'Because I'm too old and sick, if you were a boss you wouldn't look for a forty-year-old sick person, it's this simple.' Similarly, another recipient in the same city at the same time declared that: 'Everything requires a high educational background, but I only have primary school education, so naturally they won't hire me. Talented people are numerous; they won't take me. You say go to sell things, but that needs startup money (benqian). Private businesspeople won't hire us, and private bosses have no reason to ask a sick, old person to work, right?'

\section{A Cultural Explanation}

Once laid off from enterprises, older workers are seen as of no use. So it is felt that it is best to keep them barely alive, but not as a part of society. It is better to leave them unemployed and stuck in their homes, out of sight. Do not waste resources, let them die off, is the implicit message. So let's view the laid-off, sick, and older urban people as metaphors for Mao's society. It seems that those people, along with that society, should be obliterated. The market is modern, and it cannot absorb them. Modern is middle class - a state that is impossible to reach for these laid-off workers and their children.

And there has been no real effort to help them break out of their impoverishment, as an inter-generational cycle of poverty gears into motion. True, Party leader Xi Jinping promises an end to poverty in the near future, but it is only rural poverty to which he alludes, which, as noted above, can be addressed by targeting funds and services to whole areas of the countryside. There has been almost no mention of the urban poor. Thus, while the future of China can be viewed as a beautiful dream, the past remains depicted as a nightmare, filled with poverty, backwardness, and obsolescence. The poor are the antithesis of the dream, of the market, of economic growth, of progress, and glory. When multitudes of the old 'masters' of society (as state workers were labelled in the past) raged in the roads, the dibao was established to calm them down. But a policy devised mainly for stability waned as the beneficiaries went back home, out of sight. So as the project achieved its political purpose, its funds have diminished, relatively speaking. This is a tale of poverty and of precarity that never gets told. 
This text is taken from Gilded Age: A Year of Chinese Labour, Civil Society, and Rights, Made in China Yearbook 2017, edited by Ivan Franceschini and Nicholas Loubere, published 2018 by ANU Press, The Australian National University, Canberra, Australia.

$$
\text { doi.org/10.22459/MIC.04.2018.06 }
$$

